\title{
The role of individual ambidexterity for organizational performance: examining effects of ambidextrous knowledge seeking and offering
}

\author{
Benedikt Schnellbächer $^{1}$ (D) $\cdot$ Sven Heidenreich ${ }^{1}$ (D)
}

Published online: 20 March 2020

(C) The Author(s) 2020

\begin{abstract}
Empirical research has confirmed positive effects of organizational ambidexterity for companies' long-term performance. More recent research has shifted the focus from organizational level exploration and exploitation to the individual in order to understand psychological micro-foundations of individual ambidexterity. However, our current knowledge on how knowledge flows within individual ambidexterity are initiated and affect performance outcomes is limited. This study thus strives to shed light on the topic by introducing two mechanisms, namely ambidextrous knowledge seeking and ambidextrous knowledge offering, that capture how knowledge flows within individual ambidexterity are initiated. Based on surveydata from 415 employees, findings from structural equation modeling provide first empirical evidence that the focal constructs significantly affect knowledge accumulation on the department level as well as its performance. Finally, results from additional moderation analysis indicate, that ambidextrous knowledge offering leads to higher performance effects in environments characterized by the pursuit of radical innovations, while ambidextrous knowledge seeking is rather suited for environments with a focus on innovating incrementally.
\end{abstract}

Keywords Exploration · Exploitation $\cdot$ Radical innovation

JEL Classification O32 $\cdot \mathrm{D} 80 \cdot \mathrm{D} 83$

\section{Introduction}

Past research on organizational ambidexterity highlights that long-term success depends on exploring new opportunities as well as simultaneously exploiting existing capabilities already used within the company (Andriopoulos and Lewis 2010; March 1991; Uotila 2018). Nowadays, companies face the challenge to exploit existing knowledge resources

Benedikt Schnellbächer

benedikt.schnellbaecher@uni-saarland.de

Sven Heidenreich

Sven.Heidenreich@uni-saarland.de

1 Saarland University, P.O. 1511 50, 66041 Saarbrücken, Germany 
and simultaneously to explore new resources to enhance their performance (Cohendet and Laurent 2007; He and Wong 2004). Specifically, the shift to mobile connectivity and collaboration exacerbates rather than ameliorates the challenge for companies to provide structures in support of exploring new knowledge as well as simultaneously utilizing existing knowledge at an individual level (Bresciani et al. 2018; Cash et al. 2008).

After a vast array of earlier research has focused on organizational ambidexterity, recent research shifted the focus on exploration and exploitation to the granular level of employees in organizations (Gurtner and Reinhardt 2016; Schnellbächer et al. 2019; Suh et al. 2019). A focal point of individual ambidexterity is the utilization of exploration and exploitation at an individual level to foster knowledge accumulation and enhance performance (Mom et al. 2007). Within this respect, researchers highlight the importance of investigating the effects of individual level exploration and exploitation to boost long-term performance on different company levels (Mom et al. 2015; Schultz et al. 2013). Nonetheless, despite the acknowledgment of individual ambidexterity as potential driver of effective knowledge accumulation and organizational performance, research into how individual ambidexterity is initiated (Mom et al. 2007), whether and how it affects knowledge accumulation and performance (Mom et al. 2007, 2015), and which contextual factors facilitate or inhibit potential effects, is quite rare (Szulanski et al. 2016). Without insights into these issues, it remains unclear whether the implementation of appropriate structures to promote individual ambidexterity in pursuit of effective knowledge accumulation and performance enhancements pays off in the long run. This would be rather problematic as without a deeper understanding, the structures meant to promote individual ambidexterity might nurture not desired behavior resulting in potential inefficiencies and in the worst-case behavior diametrically opposed to the well-being of the organization (Bodwell and Chermack 2010).

The study at hand addresses these issues by contributing to the literature in three major ways: First, two specific types of individual ambidexterity, ambidextrous knowledge seeking and ambidextrous knowledge offering, are introduced as focal constructs to capture knowledge flows at the individual level. These constructs are especially promising as they represent the starting point of exchanging novel (Franke et al. 2013; Bierly et al. 2009) and complementary knowledge (Chen et al. 2018) and thus also the beginning of exploration and exploitation activities as well as by extension ambidextrous behavior.

Secondly, effects of these constructs on knowledge accumulation and performance are empirically tested to gain first insights into their potential contribution in achieving a sustainable advantage for companies. Addressing this question is only straightforward, because the initiation of ambidextrous seeking and offering might be inefficient due to its dual nature, namely the exploration- and exploitation-alignment, which could result in an ambiguous impact on transferring knowledge between parties, such as technology transfer, in companies (Landry et al. 2007).

Finally, the innovation-focus of the department as important contextual factor for knowledge flows is assessed, to empirically explore whether performance effects of ambidextrous knowledge seeking and ambidextrous knowledge offering differ depending on the degree of project innovativeness present in organizational units. Hence, this study provides first empirical insights on whether and how individual ambidexterity can be used to promote effective knowledge accumulation and department performance depending on the innovation-focus of the organizational unit. Next to the general importance of gaining insights into contextual factors of individual ambidexterity to better design structures fostering ambidexterity (Raisch et al. 2009), a greater understanding of the departments' innovation focus is particularly relevant, because the creation of units dedicated to radical innovations and separate units dedicated to the pursuit of incrementally innovating is one of the dominant 
approaches for implementing organizational ambidexterity on the company level (O'Reilly and Tushman 2013; Tushman and O'Reilly 1996). Therefore, a greater comprehension for its effect on lower level ambidexterity, concretely the potential, manifestation of individual ambidexterity, is of utmost relevance for organizations following this approach.

The remainder of this paper is structured as follows. First, the conceptual foundations of this study are laid out and subsequently transferred into a compact research model on knowledge flows and effects of individual ambidexterity. Afterwards, the research model is empirically validated using structural equation modeling on data from 415 employees. Finally, the results are discussed and potential implication and limitation of this study are outlined.

\section{Conceptual development}

\subsection{Individual ambidexterity}

The search for new knowledge as an important prerequisite to innovate products and services has been acknowledged by several studies Franke et al. (2013), Hansen (1999), Zhang et al. (2017). Within this respect, several authors acknowledge individual ambidexterity which refers to the utilization of knowledge generated through exploration and exploitation processes at an individual level in order to achieve effective knowledge accumulation that fosters performance (Gurtner and Reinhardt 2016; Mom et al. 2007, 2015). Following the ambidexterity logic, one might look for complementing knowledge to exploit already available knowledge or one might seek for novel knowledge to explore entire new approaches (Schulz 2001).

While both, the exploitative as well as the explorative dimension of individual ambidexterity is well defined in literature, much less discussed is the differentiation of knowledge seeking and knowledge offering as levers to utilize explorative and exploitative knowledge. In order to capture individual ambidexterity most comprehensively, we suggest to differentiate two independent yet interconnected types of individual ambidexterity: (1) ambidextrous knowledge seeking as the dual pursuit of novel and complementary knowledge to ones existing skill set within a certain time period, and (2) ambidextrous knowledge offering as the dual supply of novel and complementary knowledge to the skillset of other individuals within a certain time period. Both concepts are of particular importance as they represent the start of ambidextrous knowledge-related behavior and by extension of ambidextrous behavior as understood in earlier research (see for example Birkinshaw and Gibson 2004; March 1991). The reasoning behind this is that ambidextrous behavior consists of the combination of exploration and exploitation activities, which are initially fueled by radically novel (in the case of exploration) (Franke et al. 2013; Bierly et al. 2009) and complementary (for exploration) knowledge (Chen et al. 2018). Going further, the requisite of this knowledge acquisition is the initial seeking or offering of knowledge to gain first insights. Following this reasoning, ambidextrous knowledge seeking and offering can be described as the initial spark for ambidextrous knowledge-related behavior and arguably ambidextrous behavior in general.

Although, a vast amount of studies has confirmed positive performance effects of organizational ambidexterity (Blindenbach-Driessen and van den Ende 2014; He and Wong 2004; Hill and Birkinshaw 2014), empirical evidence on performance effects of individual ambidexterity is rather lacking (Raisch et al. 2009). Yet, some studies provide anecdotal evidence, that the simultaneous utilization of explorative and exploitative knowledge at an 
individual level might contribute to effective knowledge accumulation that fosters organizational performance (Gupta et al. 2006; Tushman and O'Reilly 1996). This corresponds with the understanding, that knowledge represents an essential resource for companies and that its transfer through the company increases the chance to appropriately employ it (Grant 1996). A straightforward example for beneficial knowledge and its transfer can be found in technology. Technology as subcategory of knowledge (Gopalakrishnan and Santoro 2004) consists of knowledge about instruments for changing the environment, usually documented in "publications, software and blueprints" (Landry et al. 2007). It appears rather plausible, that the accumulation of such knowledge and its dissemination throughout the company may have a positive impact on performance.

Independent of the applied mechanism to achieve ambidexterity, if individual ambidextrous behavior is achieved, research indicates positive performance effects for the organizational unit in which it is achieved (Gibson and Birkinshaw 2004; Walrave et al. 2017). More specifically, individual ambidexterity should foster effective knowledge accumulation and thus leads to a broad knowledge base that helps companies to more effectively generate radical innovation compared to companies with only a deep understanding of a particular knowledge area (Zhou and Li 2012). The underlying logic is straightforward. An organization with knowledge in a variety of heterogenous disciplines is able to explore potential possibilities to combine the different streams and create complex and novel approaches to innovate (Kogut and Zander 1992). As a result, the probability to achieve competitive advantages is enhanced, leading to positive performance effects.

In a well-received publication, Schultz et al. (2013) scrutinized the relationship between German surgeons' engagement in exploration as well as exploitation activities. The study operationalized exploration as the time spend on publishing activities and exploitation as the time dedicated towards medical care. The examination found that the time spend on both forms of activities increased R\&D performance, which in turn was estimated by single doctors' total citation numbers. A more recent study by Mom et al. (2015) gauged the effects of exploring and exploiting managers, concluding that ambidextrous managers regarded their performance as significantly of higher value than managers focusing only on either exploration or exploitation.

Next to the fact that due to the small number of empirical studies on individual ambidexterity corresponding empirical evidence on potential performance effects is scarce in general, none of the previous studies have accounted for the different levers to accumulate explorative and exploitative knowledge on the individual level. Consequently, theoretical rationales as well as empirical evidence on performance effects of ambidextrous knowledge seeking and offering is completely absent. In order to close this research gap, we subsequently provide theoretical rationales for performance effects of ambidextrous knowledge seeking and offering, before assessing their contribution empirically.

\subsection{Ambidextrous knowledge seeking and performance}

Individual ambidexterity encompasses two distinct but intertwined knowledge generating mechanisms that trigger knowledge flows between individuals in organizations, namely (1) ambidextrous knowledge seeking and (2) ambidextrous knowledge offering.

Ambidextrous knowledge seeking refers to processes that focus on finding complementary knowledge to ones own skillset to incrementally improve established processes, namely exploitative knowledge seeking (Birkinshaw and Gibson 2004; March 1991) and to obtain novel knowledge to ones skillset to shake up existing procedures and implement 
superior ways to conduct business, in other words explorative knowledge seeking (March 1991). Exploitative knowledge seeking expands the available knowledge base, which is complementary to the established processes (Chen et al. 2018) known in the own department. Prior, relevant knowledge of the tasks in question enables the seeker to adapt the search strategy (Brucks 1985) as well as the search locations (Moorman et al. 2004) according to the knowledge domain and by this to effectively identify further, performance-enhancing information (Barrick and Spilker 2003). The utilization of knowledge provided by actors' familiar with the own knowledge domain (e.g. own market, role of the department, etc.) fuels incremental innovations (Tödtling et al. 2009), which again enhances performance of the department (Bhaskaran 2006). Still, taking the long-term perspective, an everlasting requirement to stay in business is not only to improve processes over time, but also to continuously adapt one's processes to changes in the environment to avoid rendering processes obsolete by unprepared disruptions in the market place (Benner and Tushman 2003). Explorative knowledge seeking aims to integrate novel concepts, new paradigms and general knowledge, which might be disruptive to existing processes in the department. Such knowledge is an important ingredient for highly innovative products, (Franke et al. 2013) services (Leiponen 2005) and processes (Dewar and Dutton 1986). Explorative knowledge seekers are exposed to radically different ways of conducting business (Bierlyet al. 2009) and by extension the work in their respective department. They can choose to pursuit promising knowledge streams further to acquire in-depth, beneficial knowledge, when first shallow access deems it worthwhile (Yli-Renko et al. 2001), or simply be inspired by the diverging ways to work and combine them with known approaches to create something new (Ward 2004). In turn, they are enabled to radically affect the processes and procedures of their own working place. Hence, based on the theoretical discussion above, it seems that ambidextrous knowledge seeking, based on both exploitative and explorative means, positively affects performance. In line with proposed performance effects of exploitative knowledge seeking, findings from Tödtling et al. (2009) show, that knowledge from partners within the same business sector positively affects the creation of incremental innovations, which are widely seen as source for profitability and sustained performance (Bhaskaran 2006). Likewise, with respect to the proposed performance effects of explorative knowledge seeking, Leiponen (2005) found evidence that the access to external, untypical knowledge improves the introduction of radical innovations. In conclusion, both theoretical consideration as well as empirical evidence from adjacent domains suggest that ambidextrous knowledge seeking may create novel knowledge, fueling radical innovations to enhance performance on the department level. On this base, it can be assumed:

Hypothesis 1 Ambidextrous knowledge seeking enhances department performance.

\subsection{Ambidextrous knowledge offering and performance}

Ambidextrous knowledge offering refers to all processes that focus on distributing novel explorative and complementary knowledge to others (Mom et al. 2007; Schulz 2001). Exploitative knowledge offering supports improvements by the rapid diffusion of knowledge, which supplements existing processes. This way best practices of departments with comparable tasks or problems can be "copied" to the own department (Szulanski and Jensen 2004). Furthermore, exploitative knowledge offering can be used to incrementally improve existing processes. The effects on the own department might be direct as well as indirect. On one hand knowledge might be offered to colleagues in the own department, 
which enhances the performance on the department level. On the other hand, knowledge might be offered to individuals outside of the department. This might not directly affect the performance of the own organizational unit, but it increases the chance of receiving additional resources, such as but not limited to knowledge, in the future by the beneficiaries of the shared knowledge. The rich literature on knowledge sharing in general and on Communities of practice $(\mathrm{CoP})$ in specific suggests positive performance effects of exploitative knowledge offering (Schenkel and Teigland 2008). Yet, business functions need to radically renew their processes over time to stay competitive (Montazemi et al. 2012; Tarafdar and Gordon 2007). Explorative knowledge offering might help in this regard by enabling the dissemination of knowledge, which is radically different and entirely unrelated to the knowledge of the respondent, that it is offered to. As such novel knowledge is the main resource in generating radical innovations (Zhou and Wu 2010), accumulating it might help to disrupt the competitive environment and create new opportunities (Smith and Tushman 2005), which are needed to achieve long-term success (Leifer et al. 2001; McDermott and O'Connor 2002). Hence, the offering of novel knowledge to others in the department may facilitate the generation of novel ideas and subsequently radical innovations to improve performance in the department. Again, a direct as well as an indirect channel exist how offering knowledge might affect department performance depending on whether the receiver of the offered knowledge is part of the own department or outside of it by either creating a direct effect on department performance or unlocking potential resources for the department by creating goodwill. Following both lines of reasoning, it can be assumed that process improvements by exploitative knowledge offering and idea generation by explorative knowledge offering enhance performance. Hence, it is proposed:

Hypothesis 2 Ambidextrous knowledge offering enhances department performance.

\subsection{The mediating role of knowledge accumulation}

Independent of the direct effect of ambidextrous knowledge seeking and offering on department performance, a second, indirect connection between the constructs exists. Ambidextrous knowledge seeking and offering are closely entangled with knowledge accumulation within the department as both activities represent the initiation phase of a knowledge flow (Mom et al. 2007; Szulanski 2000). Like all knowledge transfer activities, ambidextrous knowledge seeking and ambidextrous knowledge offering are positively connected to the knowledge stock of the organizational unit. Knowledge seeking expands one's own knowledge, thus the accumulated knowledge of the department, and offering of knowledge to colleagues within the department also increases the knowledge stock of the department as more department members possess it. Moreover, knowledge offering to players outside of the department increases the accessibility of knowledge and other resources for the department as it increases the goodwill to share them with the department in the future. Knowledge repositories offer the possibility to store acquired knowledge for future usage, so it doesn't have to be immediately translated in performance-relevant activities (Jasimuddin et al. 2012). The storage might be via the usage of a community (Lee and Cole 2003) or a computer-assisted repository (Jasimuddin et al. 2012). Independent of the exact means of storage, accumulated knowledge can be saved for utilizing it in the future. Naturally, the value of some of the knowledge deteriorates over time (de Holan and Phillips 2004; von Krogh et al. 2001). Nonetheless, vast research indicates a positive connection between knowledge accumulation and performance (Decarolis and Deeds 1999; Melville et al. 
2004). In 1999 Decarolis and Deeds studied biotechnology firms and established a positive link between the knowledge stock, estimated by products in the research pipeline, research citations and granted patents, and market value. Later, SubbaNarasimha et al. (2003)were able to identify a positive effect of accumulated knowledge on return on capital as well as sales growth in the American pharma sector with data ranging from 1967 to 1972. Finally, Lee and Huang (2012) also found a significant effect of knowledge stock on the return on assets. Considering the above made argumentation, it can be proposed:

Hypothesis 3 Knowledge accumulation mediates the effects of ambidextrous knowledge seeking and ambidextrous knowledge offering on department performance.

H3a Ambidextrous knowledge seeking enhances knowledge accumulation.

H3b Ambidextrous knowledge offering enhances knowledge accumulation.

H3c Knowledge accumulation enhances department performance.

\subsection{The moderating role of innovation-focus of the department}

Designing and implementing appropriate structures to facilitate ambidexterity requires a deeper understanding of the contextual factors influencing it (Raisch and Birkinshaw 2008). Various ways to implement ambidexterity are debated in the scientific community (Birkinshaw and Gupta 2013; O'Reilly and Tushman 2013; Raisch et al. 2009). The most prominent approach centers around the department (level): spatial separation tries to enhance performance by dedicating some departments to the pursuit of radical improvements (e.g. R\&D, innovation) and some departments to enabling incremental innovations (e.g. production, accounting) to leverage synergies (Jansen et al. 2009; Raisch et al. 2009).

Department that are focused on radical innovations have to process highly novel and complex knowledge on a daily basis, because exactly those novel (Gopalakrishnan and Bierly 2001; Pérez-Luño et al. 2011) and complex (Pérez-Luño et al. 2011) knowledge propel the creation of radical innovation. Those aspects require a deep and fine-grained understanding for the transfer of such knowledge to succeed. Without such an expert, the identification of beneficial, novel knowledge is very difficult, due to the uncertainty and untested nature of novelty (Gopalakrishnan and Bierly 2001; Pérez-Luño et al. 2011). Moreover, the complexity increases the amount of information, which must be processed to acquire it (McEvily and Chakravarthy 2002), thus making it costlier to gain knowledge, which value is not yet clear. Those circumstances put any knowledge seeker in a sizable disadvantage, because it is difficult to recognize appropriate opportunities to transfer (Szulanski 2000). On the other hand, a knowledge supplier should not be obstructed, because as a supplier one is already privy to the knowledge and consequently has a superior grasp of its potential worth. This mechanism should not be affected, whether or not the knowledge is offered to colleagues within the department for the benefit of it or to individuals outside of the department to unlock access to resources outside of it. The picture changes in departments dedicated to incremental innovations. The lower complexity and novelty allow an easier identification of valuable knowledge (Gopalakrishnan and Bierly 2001; Pérez-Luño et al. 2011) as well as a more efficient processing of it (McEvily and Chakravarthy 2002). A knowledge seeker may gain without greater costs a broad knowledge base of sought after topics. On the other hand, a provider of knowledge has to first identify appropriate targets for a beneficial knowledge transfer. In a field, where the acquisition of knowledge is relative easy, this is 
rather inefficient. Considering this connection, it can be assumed, that the performance effects of ambidextrous knowledge seeking are maximized in contexts dedicated to the pursuit of incremental innovations, while ambidextrous knowledge offering is especially useful in contexts dedicated to the pursuit of radical innovations. Thus:

Hypothesis 4 Innovation focus of the department moderates the effects of ambidextrous knowledge seeking and ambidextrous knowledge offering on department performance.

H4a The positive effect of ambidextrous knowledge seeking on department performance decreases with a higher focus on radical innovations.

H4b The positive effect of ambidextrous knowledge offering on department performance increases with a higher focus on radical innovations.

\subsection{Covariates}

Next to the proposed relationships between ambidextrous behavior, knowledge accumulation, department performance and innovation focus, earlier research suggests organizational and sociodemographic factors, which additionally influence the relationship between ambidexterity-related behavior and performance (e.g. Jansen et al. 2009; Mom et al. 2009). Hence, the study includes company size, company age, department size, gender, age and work experience as controls. The inclusion should strengthen the robustness of the hypotheses tests.

In Fig. 1 the research model's hypothesis framework is summarized.

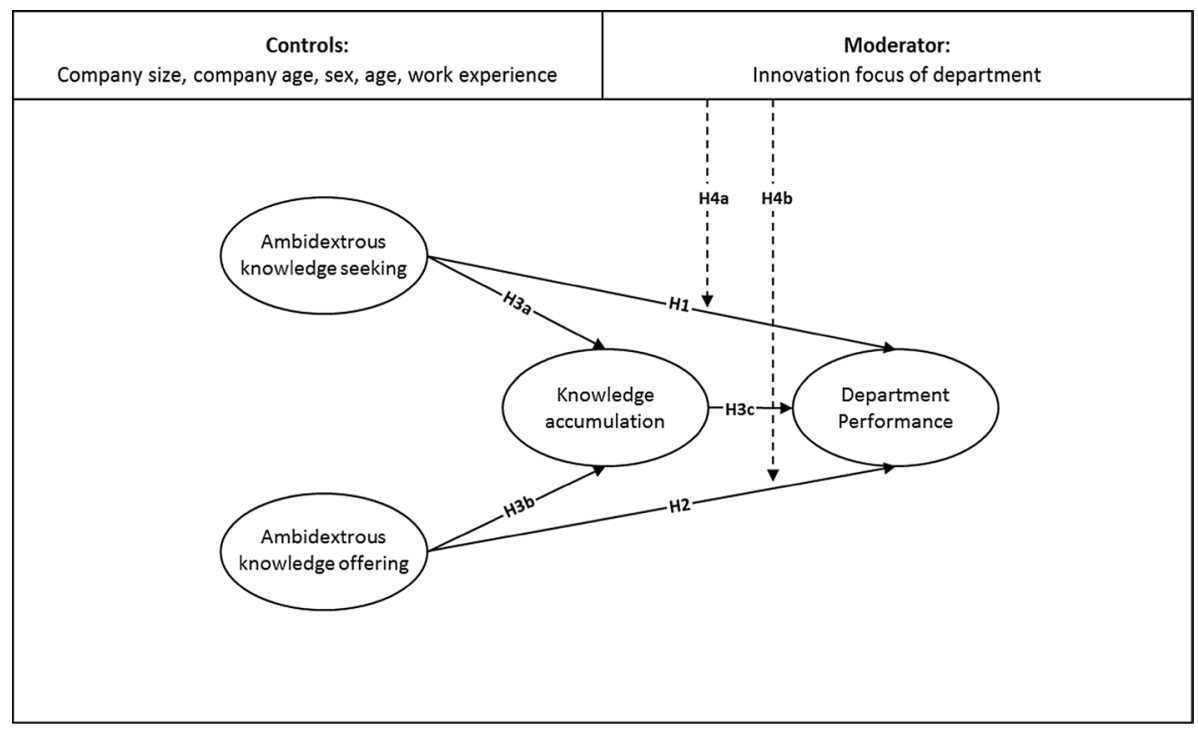

Fig. 1 Research model 


\section{Research design}

\subsection{Sample and data}

The study employs an online questionnaire to gather a sample of German employees. A market institute was tasked to randomly collect data from German employees, because every individual is able to engage in exploration as well as exploitation-oriented activities (Birkinshaw and Gupta 2013; Gibson and Birkinshaw 2004). During the data collection, it was ensured that not several respondents provided information from the same company, thus preventing the occurrence of nested data. In total, 415 responses were collected, which split into $53 \%$ female and $47 \%$ male replies. The average age of the respondents was 35 years. While this is quite low, the data are representative regarding the industry structure of the German economy and the analysis controls for age to avoid any bias due to the factor. Table 1 depicts a detailed breakdown of the data set characteristics. At the beginning of the questionnaire, it was assured to the respondents that the answers would be confidential to reduce the probability of social desirability bias. Furthermore, the full collinearity assessment method is used to test for potential common method variance. The factor-level VIF results are below 3.3 and thus indicate the absence of common method bias (Kock 2015).

\subsection{Measures}

The study defines ambidextrous knowledge seeking as the dual pursuit of complementaryand radically novel knowledge respective to one's own skillset within a certain period of time. Moreover, ambidextrous knowledge offering is defined as the dual provision complementary and novel knowledge relative to the skillset of the other party within a time period. For ambidextrous knowledge seeking (Davis 1989; Phang et al. 2009) and ambidextrous knowledge offering validated scales by information system literature (Davis 1989; Kankanhalli et al. 2005) are further developed to fit to the exploration and exploitation dimensions of ambidexterity research (Mom et al. 2009). In line with research on individual ambidexterity, this study operationalizes the focal constructs ambidextrous knowledge seeking and ambidextrous knowledge offering as Type 2, reflective-formative, constructs (Mom et al. 2009, 2015). Hence, the first-order constructs of explorative knowledge seeking and exploitative knowledge seeking are combined in the second-order construct ambidextrous knowledge seeking and analogous the first-order constructs explorative knowledge offering and exploitative knowledge offering are conflated in the higher-order construct ambidextrous knowledge offering. Explorative and exploitative knowledge seeking are comprised of 8 items, 4 for search activities inside the organization and the same amount for search endeavors outside the organization. Explorative and exploitative knowledge offering consist each of 4 items encompassing knowledge offering to colleagues (inside the company). All items range on a 7-Likert scale from "very strongly disagree" to "very strongly agree".

Knowledge accumulation includes the generation of ideas, expertise and competences, which can be applied in the future. The construct is operationalized by using a reflective, three-item construct of Brettel et al. (2012). Department performance contains the meeting of the department's goals, staying on budget and meeting operational/technical performance indicators. The applied, reflective construct of three items 
Table 1 Sample characteristics

\begin{tabular}{|c|c|c|c|c|}
\hline Sample characteristics & Industry & Company age & $\begin{array}{l}\text { Educational back- } \\
\text { ground }\end{array}$ & Job type \\
\hline Automotive & $7 \%$ & & & \\
\hline Banking & $7 \%$ & & & \\
\hline Building & $2 \%$ & & & \\
\hline Chemicals & $2 \%$ & & & \\
\hline Manufacturing & $6 \%$ & & & \\
\hline Insurance & $3 \%$ & & & \\
\hline IT/software & $6 \%$ & & & \\
\hline Logistics & $16 \%$ & & & \\
\hline Pharma & $20 \%$ & & & \\
\hline Public sector & $3 \%$ & & & \\
\hline Telecommunication & $2 \%$ & & & \\
\hline Trade & $11 \%$ & & & \\
\hline Transport & $3 \%$ & & & \\
\hline Other services & $12 \%$ & & & \\
\hline$<5$ years & & $7 \%$ & & \\
\hline 5-10 years & & $12 \%$ & & \\
\hline $11-20$ years & & $15 \%$ & & \\
\hline $21-50$ years & & $30 \%$ & & \\
\hline$>50$ years & & $36 \%$ & & \\
\hline University degree & & & $38 \%$ & \\
\hline College degree & & & $36 \%$ & \\
\hline Vocational training & & & $15 \%$ & \\
\hline Secondary school degree & & & $9 \%$ & \\
\hline Primary school degree & & & $2 \%$ & \\
\hline Upper management & & & & $6 \%$ \\
\hline Middle management & & & & $15 \%$ \\
\hline Young executives & & & & $6 \%$ \\
\hline Employee & & & & $55 \%$ \\
\hline Craftsman & & & & $10 \%$ \\
\hline Other & & & & $8 \%$ \\
\hline
\end{tabular}

also stems from Brettel et al. (2012). The 7-likert scaled items are also ranging from "very strongly disagree" to "very strongly agree".

The innovation focus of the department encompasses the alignment of the department to exploration or exploitation-related activities. To operationalize the construct, the scales of Jansen et al. (2009) were used. The construct contains four items, anchored on a 7-likert scale to the terms "very strongly disagree" to "very strongly agree".

Concerning the controls, company age, age and work experience were assessed in completed years. Company size and department size were measured in number of employees. 


\section{Analyses and results}

\subsection{Analysis}

In order to investigate the proposed research model of several latent constructs, component-based structured equation modeling (SEM) was applied (Chin and Newsted 1999; Fornell and Bookstein 1982; Vinzi and Russolillo 2013). The partial least squares (PLS) variation of SEM was chosen due to the limitations of the covariance-based approach to model formative second-order constructs, such as the constructs ambidextrous knowledge seeking as well as offering (Chin 2010). The software SmartPLS 2.0 was used to estimate the parameters of the model (Chin 1998; Tenenhaus et al. 2005), employing path weighting scheme with 5000 iterations and case-wise replacements for missing data. Moreover, nonparametric bootstrapping was employed to determine the standard errors and subsequently to assess the significances (Chin 1998; Tenenhaus et al. 2005). The resampling followed the individual level change procedure (Henseler et al. 2009). To test the hierarchical constructs ambidextrous knowledge seeking and ambidextrous knowledge offering, the study applied the repeated indicator approach (Wetzels et al. 2009). The proposed mediation effect of hypothesis 3 was assessed by calculating the z-statistic to estimate, if the differences between the model with and without the inclusion of the knowledge accumulation mediation is indeed significant (Sobel 1982). To grasp the moderating effect of the innovation focus level on the relationship between ambidextrous knowledge seeking/ambidextrous knowledge offering on knowledge accumulation and department performance (Hypothesis 4), a PLS multigroup analysis was deployed (Hair et al. 2013). The sample was separated into two subsamples by applying a median split to the innovation focus variable. Values of innovation focus exceeding the median were put into the "radical innovation focus" category and values below the median were put into the "incremental innovation focus" category. Afterwards, the research model was run for both subsamples. The significances of the differences between each effect were measured using a two independent-samples $t$ test (Keil et al. 2000).

The study conducted several procedures to reduce the risk of potential biases. In an exploratory factor analysis, the Harman's single-factor test was conducted. No factor surpassed $50 \%$ of the total variance, which indicates a low risk of of common method bias (Podsakoff et al. 2003; Podsakoff and Organ 1986; Tiwana and Keil 2007). Additionally, a two-sample $t$-test was conducted with the dependent variable (department performance) responses of early and later survey participants to check for any potential non-response bias (Armstrong and Overton 1977). No significant difference between early and late responses could be identified at the 5\% level. Hence, there is low risk for the presence of non-response bias (Kanuk and Berenson 1975). Furthermore, the study participants were reassured, that all information would be confidential, mitigating the risk of social desirability bias (Podsakoff et al. 2003).

The analysis followed the recommended process by Chin (2010) as well as Henseler et al. (2009) to initially evaluate the measurement model and then, in a second step, if the results in the first step are deemed adequate, to assess the structural model. 


\subsection{Results: measurement model}

The psychometric properties of the reflective measurement models were evaluated according to the properties of content validity, convergent validity, construct reliability and discriminant validity (Götz et al. 2010). Initially, the construct reliability of the constructs explorative knowledge seeking, exploitative knowledge seeking, explorative knowledge offering, exploitative knowledge offering, knowledge accumulation and department performance were evaluated by measuring for each construct the Cronbach's alpha. All Cronbach's alphas exceed the recommended minimum value of 0.70 (Nunnally and Bernstein 1994). Subsequently, the average variance extracted (AVE) was estimated to assess the convergent validity. All AVE values exceeded the threshold of 0.5 (Chin 1998). The discriminant validity was controlled by ensuring that the indicator correlations with its assigned construct (loadings) exceed the correlation with all other constructs (cross-loadings). Thus, the criteria for reflective measurement models could be met (see Tables 2, 3).

For evaluating the second-order constructs of ambidextrous knowledge seeking and ambidextrous knowledge offering, the formative indicator weights were tested for significance on the second-order construct and the constructs themselves were checked for multicollinearity (Chin 2010; Götz et al. 2010). The indicator relevance was evaluated by using bootstrapping to calculate the second-order weights. The criteria benchmark of $t>1.98$ was met by all values (Tenenhaus et al. 2005). The variance inflation factor (VIF) was checked for the second-order constructs ambidextrous knowledge seeking and ambidextrous knowledge offering. The calculated VIF values don't exceed 5, indicating absence of multicollinearity. Thus, the model could be further assessed on the structural level (Henseler et al. 2009) (see Table 4).

\subsection{Results: structural model}

The path coefficients and the accompanying significances were assessed to test the fit between structural model and the data. An overview of the results is shown in Fig. 2 . The $\mathrm{R}^{2}$ range from 0.15 to 0.45 . Hence, the fit is rather satisfactory (Fornell and Bookstein 1982). Moreover, the calculated VIF values also supports the assertion that no multicollinearity exists at the structural level (Knowledge accumulation $=1.18$; Department performance $=1.82$ ).

In line with hypothesis 1 , higher levels of engagement in ambidextrous knowledge seeking is positively associated with increased department performance $(\beta=0.13$, $p<0.05)$. Likewise, higher levels of ambidextrous knowledge offering positively influences department performance $(\beta=0.11, p<0.1)$, confirming hypothesis 2 .

The evaluation of hypothesis 3 followed the suggested procedure of Iacobucci and Duhachek (2004) for mediated relationships (Helm et al. 2010). In line with hypothesis $3 \mathrm{a}$ and $3 \mathrm{~b}$, positive relationships of ambidextrous knowledge seeking and ambidextrous knowledge offering with knowledge accumulation could be established $(\beta=0.29$, $p<0.01 ; \beta=0.14, p<0.01)$. Moreover, a positive association between knowledge accumulation and department performance could be confirmed, thus supporting hypothesis $3 c(\beta=0.53, p<0.01)$. The results of two employed Sobel tests demonstrate, that the effects of ambidextrous knowledge seeking $(\mathrm{z}$-value $=5.9424 ; p<0.01)$ 


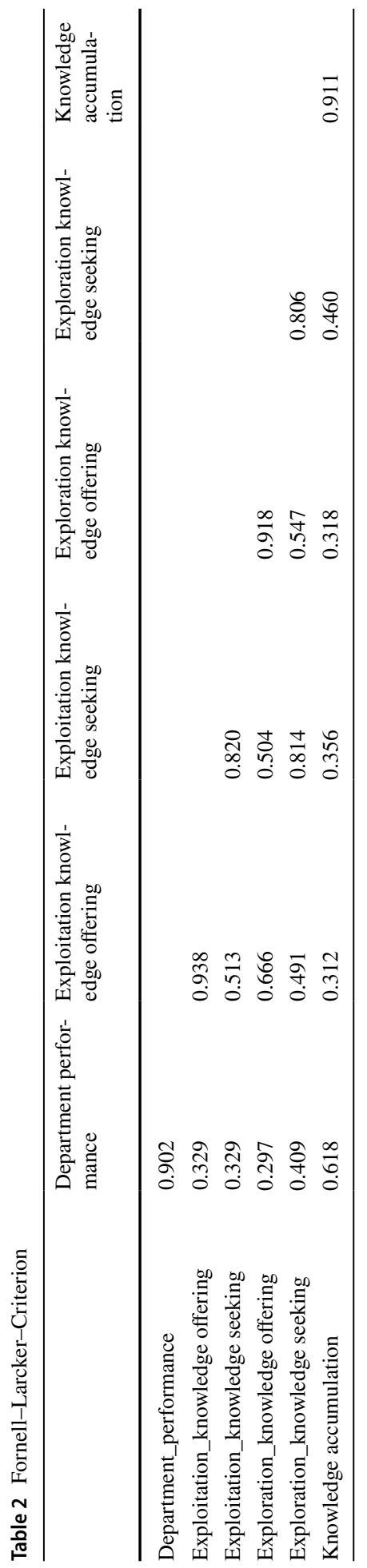




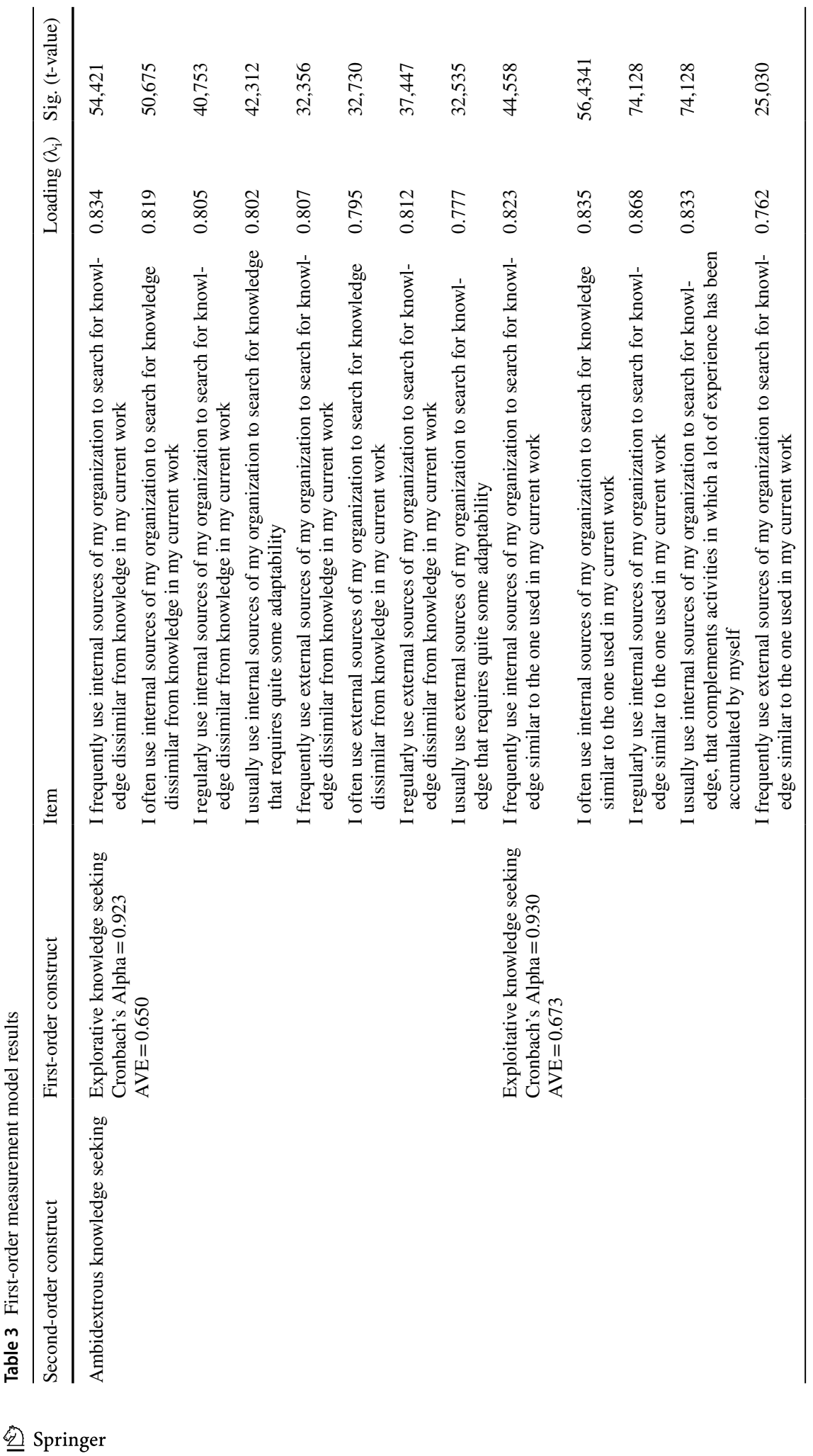




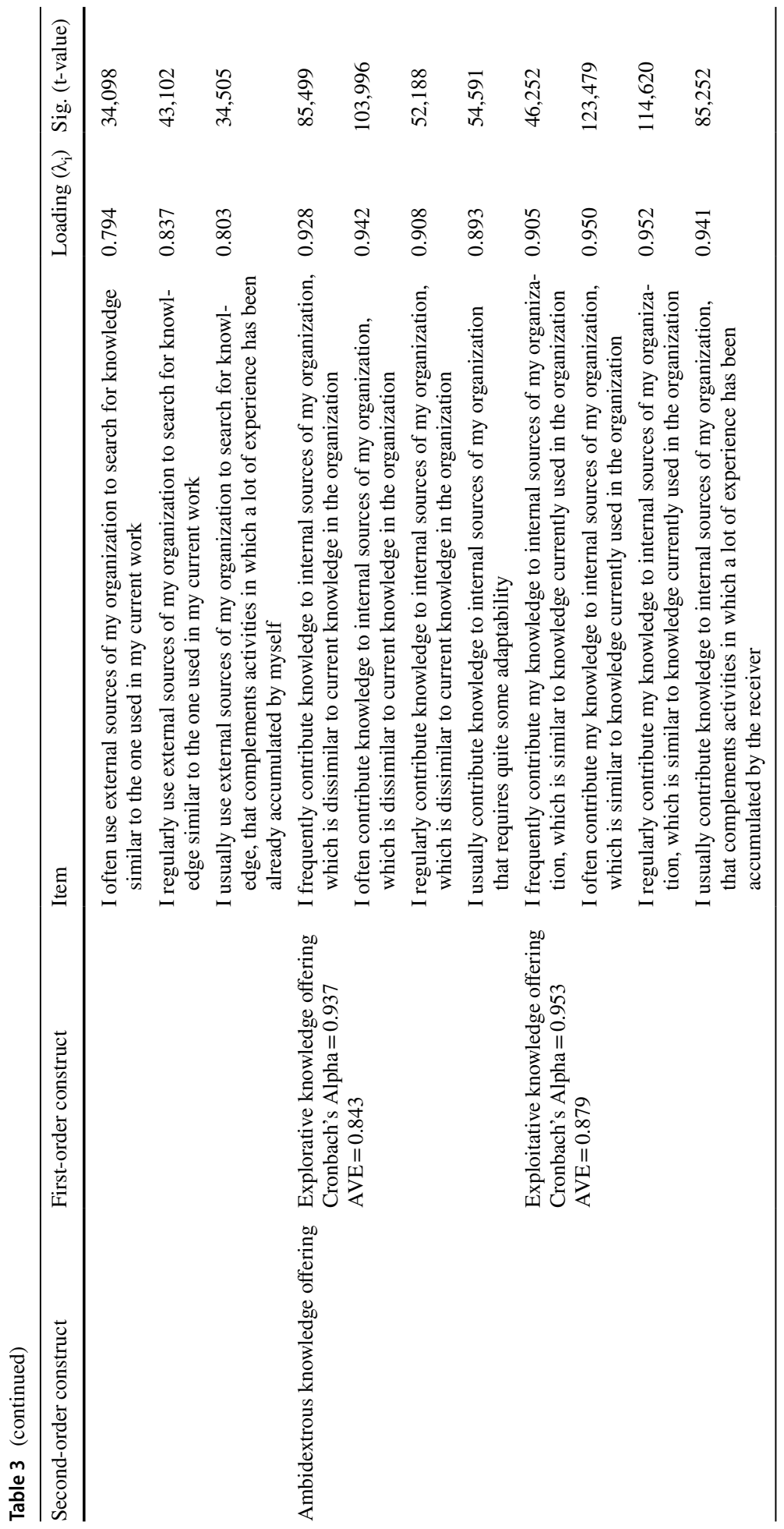




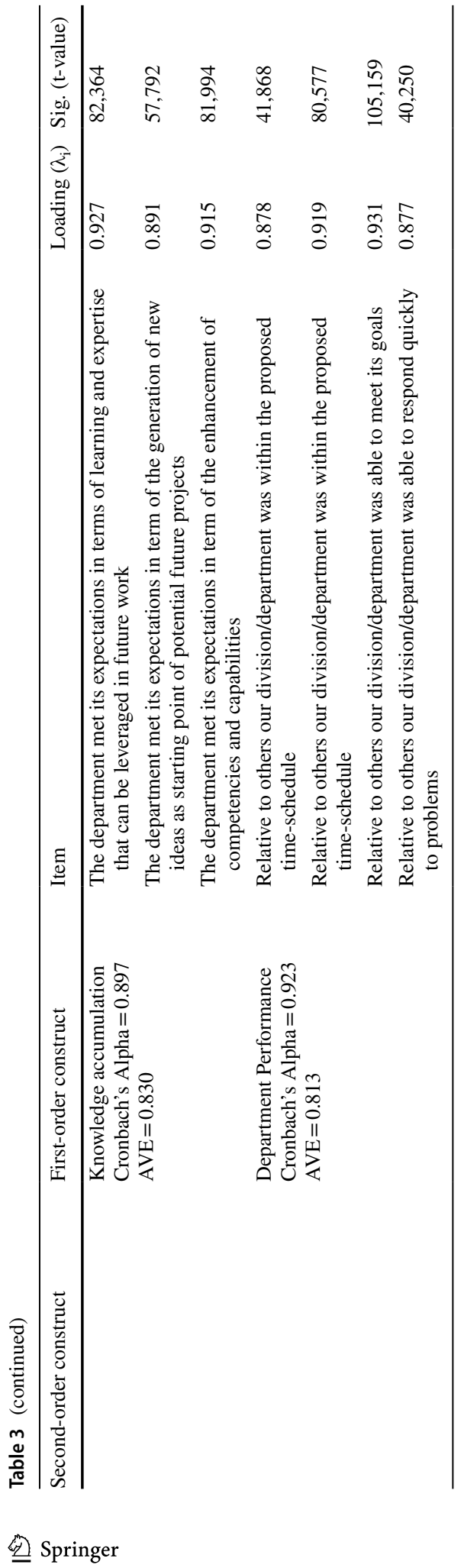


Table 4 Second-order hierarchical measurement model results

\begin{tabular}{lllll}
\hline Second-order construct & Construct label & First-order Construct & Weights & Sig. (t-value) \\
\hline $\begin{array}{l}\text { Ambidextrous knowledge } \\
\text { seeking }\end{array}$ & LV1 & Explorative knowledge seeking & 0.539 & 34.832 \\
VIF $\leq 1.32$ & LV2 & Exploitative seeking & 0.516 & 42.906 \\
$\begin{array}{l}\text { Ambidextrous knowledge } \\
\text { offering }\end{array}$ & LV3 & $\begin{array}{l}\text { Explorative knowledge offer- } \\
\text { ing }\end{array}$ & 0.521 & 61.068 \\
VIF $\leq 1.21$ & LV4 & Exploitative offering & 0.569 & 43.249 \\
\hline
\end{tabular}

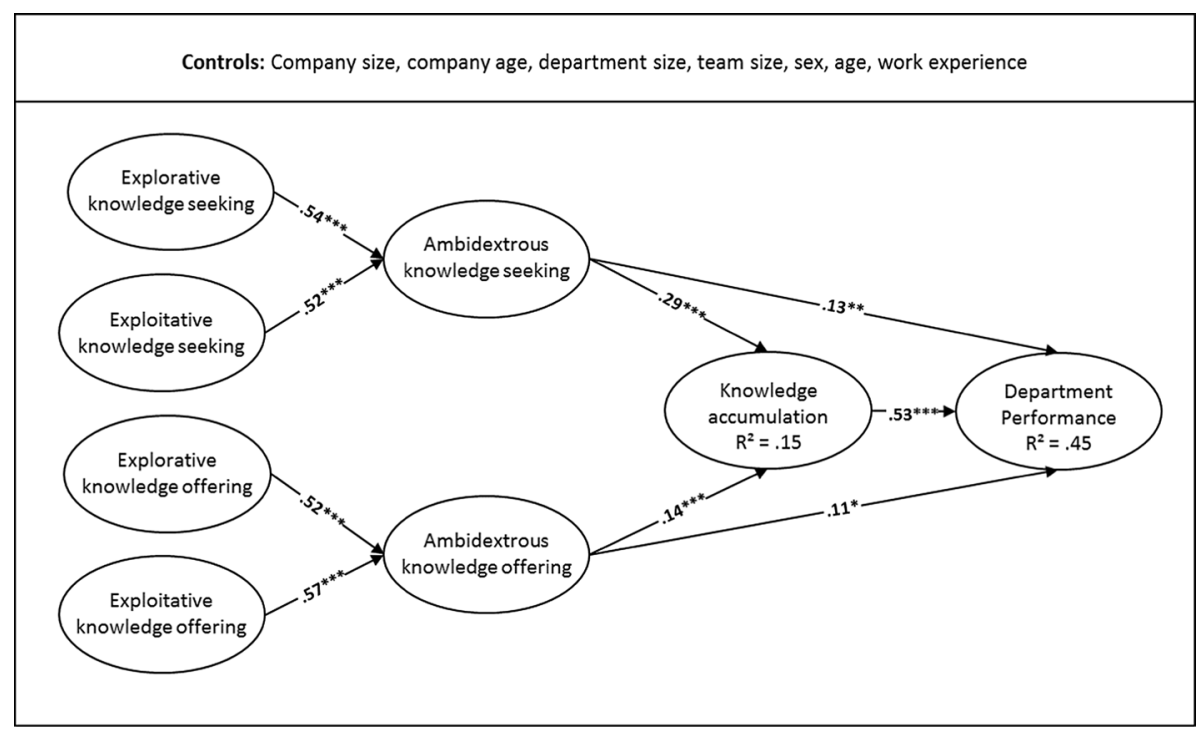

Fig. 2 Structural model results

and ambidextrous knowledge offering ( $\mathrm{z}$-value $=5.309 ; p<0.01)$ on department performance are indeed significantly mediated by knowledge accumulation.

Finally, the results of the group comparison confirm that the difference of the effect of ambidextrous knowledge seeking $(\beta$ IFhigh. $=-0.01, \beta$ IFlow. $=0.26 ; p<0.01)$ as well as for offering on knowledge accumulation ( $\beta$ IFhigh. $=0.29, \beta$ IFlow. $=0.09$; $p<0.01$ ) between both models is significant (Fig. 3). Likewise, the differences of ambidextrous knowledge seeking $(\beta$ IFhigh. $=-0.01, \beta$ IFlow. $=0.26 ; p<.01)$ and offering $(\beta$ IFhigh. $=0.21, \beta$ IFlow. $=-0.02 ; p<0.01)$ on department performance between the high innovation and the low innovation group is significant. To sum it up, the empirical results support hypothesis 4 . While no explicit moderation effect of innovation focus on the relationship between knowledge accumulation and department performance is included, the study controls for such moderation. However, the difference between the two subsamples turned out to be insignificant $(\beta$ IFhigh. $=0.56, \beta$ IFlow. $=0.45$; n.s.). 


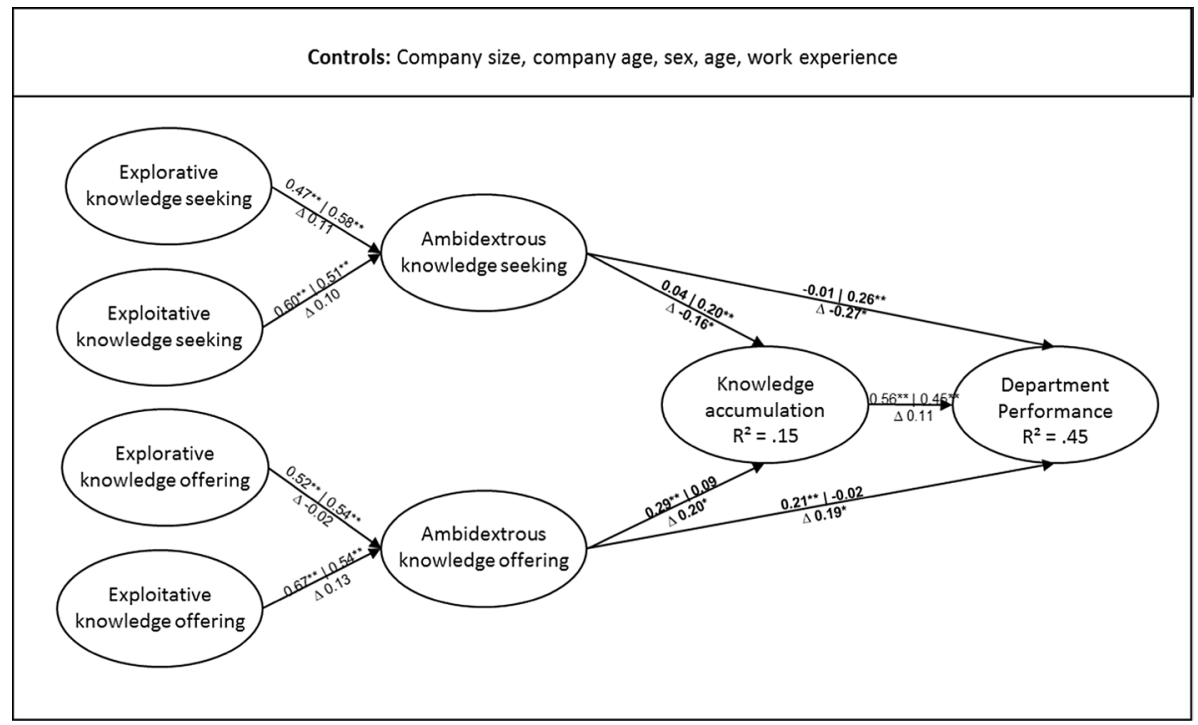

Fig. 3 Structural model: moderator Innovation focus

\section{Discussion}

Through the lens of organizational ambidexterity, long-term success depends on the ability to explore new opportunities and to exploit existing capabilities (Andriopoulos and Lewis 2010; March 1991). Younger research into ambidexterity shifted its focus to a granular level (Gurtner and Reinhardt 2016). A focal point is to understand simultaneous exploration and exploitation on the individual level to harness potential positive effects on performance (Mom et al. 2015; Schultz et al. 2013). The goals of the study were threefold: (1) the introduction of two focal constructs, ambidextrous knowledge seeking and ambidextrous knowledge offering, to capture knowledge flows at the individual level, (2) the empirical validation of the effects of those constructs on knowledge accumulation and performance (3) and lastly shedding light on how the innovation focus of departments affects the introduced constructs.

First off, the introduction of the focal constructs ambidextrous knowledge seeking and offering continuous and links two academic debates. For once, the general discussion about knowledge as a lever to enhance performance. Surely, the most prominent study about the resource knowledge in the context of organizational ambidexterity is the influential work of He and Wong (2004). While they assessed how technological knowledge can be utilized to foster innovations for the firm, our study addresses the issue of general knowledge for individual level ambidexterity and thus expands the reasoning of He and Wong as well as of other studies linking the constructs of exploration and exploitation with the construct knowledge (e.g. Cohendet and Laurent 2007; Kauppila 2018; Vrontis, et al. 2017).

Following this thought, this study also links to the debate surrounding individual ambidexterity and knowledge. As far as we are aware, Mom et al. (2007)were the first to put the issue center stage by scrutinizing the effects on exploration- and exploitation-related knowledge flows on managerial behavior. The findings are in line with the work and extend 
it by reversing the perspective and showing how individuals might initiate the passing of knowledge and which effects this produces.

Secondly, the findings are in line and enrich the literature on knowledge accumulation and firm performance (e.g. Decarolis and Deeds 1999; Jasimuddin et al. 2012, Lee and Huang 2012; SubbaNarasimha et al. 2003). The study strengthens and emphasizes the notion, that the accumulation of one's knowledge stock in a company is an essential task for fostering performance and ensuring success. Additionally, the findings accentuate that such knowledge can be fueled by rather explorative (novel) as well as more incremental (complementary) knowledge, following an idea already explored by Katila and Ahuja in the year 2002, who examined the knowledge generated by different search distances of companies in the international robotics industry.

Third, the paper enters into the dialogue about how environmental factors influence ambidexterity and its surrounding effects (Lavie, Stettner and Tushman 2010; Raisch et al. 2009). With the examination of the innovation focus, the paper builds on the publications dedicated to utilizing structural means to separate exploration units (e.g. R\&D, innovation) from exploitation units (e.g. production, accounting) to avoid frictions from the different alignments (Huang and Kim 2013; Jansen et al. 2009; O'Reilly and Tushman 2013). The findings are in line with the suggestions of those papers, that the application of organizational architecture to separate such units affects exploration and exploitation behavior. The findings complement the approach by highlighting two mechanisms, how the organizational differentiation affect behavior, namely ambidextrous knowledge seeking and ambidextrous knowledge offering, and consequently how the approach might be further refined to produce better results.

\section{Implications}

\subsection{Theoretical implications}

Taking a look at the theoretical implications, this research contributes to the scientific community in four ways. For starters, the study introduces the focal constructs ambidextrous knowledge seeking and ambidextrous knowledge offering to extend the present understanding of the initiation of individual ambidexterity. Individual ambidexterity, the simultaneous utilization of novel and complementary knowledge trough exploration and exploitation at an individual level (Gurtner and Reinhardt 2016; Mom et al. 2007, 2015), is complemented by the grasp of how such knowledge can be acquired in companies. The constructs open up a new perspective on the mechanisms of the phenomenon individual ambidexterity as well as on how it may be leveraged, by studying a new type of antecedents, concretely antecedents affecting ambidextrous knowledge seeking and offering. This way the paper enriches the traditional research into the antecedents of individual ambidexterity (e.g. Kammerlander et al. 2015; Schultz et al. 2013).

Moreover, the study contributes to the literature by empirically verifying a positive link between ambidextrous knowledge seeking as well as ambidextrous knowledge offering. Hence, the constructs on the individual level are drivers of knowledge accumulation on higher organizational levels and it establishes a new tool set for theoretical approaches depending on the accumulation of knowledge to create a competitive advantage. Most prominently, the findings might inspire some research ideas in the context of resourcebased theory (Barney 1996; Conner and Prahalad 1996) and especially its manifestation 
within knowledge-based theory of the firm (Grant 1996). Furthermore, the identified drivers also strengthen the well-trodden path between organizational learning and (organizational) ambidexterity research (e.g. He and Wong 2004; Wei et al. 2014) by not only enhancing the accumulation of a one-dimensional, specific kind of knowledge, but of a combination of complementary, incremental knowledge as well as novel, radical knowledge. The findings may serve as a new angle to foster organizational learning within companies. The beneficial effects of the simultaneous pursuit of exploration- and exploitationrelated knowledge for organizational learning are well-established (Kane and Alavi 2007). Thus, the empirically tested relationship between ambidextrous knowledge seeking and offering as antecedents of such knowledge provide the organizational learning literature with new insights of how exploration- and exploitation knowledge might be produced to kick-start learning processes.

Next to the effect on knowledge accumulation, the analysis was also able to support a positive connection between the introduced constructs and performance on the department level and thus contributes to the ongoing discussion of the performance effects of individual ambidexterity (Raisch et al. 2009). The results complement the findings of previous studies, which had to focus on very limited performance measurements, for instance the total citation number for German surgeons in a study by Schultz et al. (2013), and extend their narrow application as in the case of the study of Mom et al. (2015), which only was able to examine managers' subjective estimation of their personal performance irrespective of the team, department or the wider organization. Hence, the study contributes to the individual ambidexterity literature by emphasizing its performance enhancing characteristics.

Last but not least, the work adds insights into environmental factors supporting exploration and exploitation on the individual level (Raisch et al. 2009). The results regarding the specific innovation focus on ambidextrous knowledge seeking and ambidextrous knowledge offering not only sheds light on an environment factor for ambidexterity, but also enlightens the ambidexterity sub-streams: structural (Jansen et al. 2009) and contextual ambidexterity (Gibson and Birkinshaw 2004). The results empirically support the notion by Birkinshaw and Gupta (2013) that individual level ambidexterity exists in companies engaging in structural ambidexterity. In turn, the findings also indicate that mechanisms of structural ambidexterity like the spatial separation into innovation units (radical innovation focus) and administrative units (incremental innovation focus) affect individual level ambidexterity. The solely focus on one of the approaches may lead to the neglect of an important puzzle piece to grasp ambidexterity. Therefore, if the findings don't suggest a merging of both sub-streams, they at least indicate that studies should account for structural mechanisms as well as individual behavior to provide the full picture.

\subsection{Managerial implications}

If one takes a step back to consider the managerial implications, several recommendations can be derived from the findings. The most evident feedback to practice is to shift additional focus on the design of structures and processes to foster the initialization of individual ambidexterity. Earlier research already established the importance of individual ambidexterity (Mom et al. 2015; Schultz et al. 2013). Nonetheless, the study highlights that to unlock the full potential of individual ambidexterity, companies need to pay attention of what and how knowledge is sought after and offered to fuel exploration and exploitation endeavors. 
In practice, managers have to consider how staff can be incentivized to seek as well as to offering knowledge and not only in their own expertise, but also in knowledge areas, which are farther away from their own know-how. Unfortunately, this is easier said than done. Managers face the challenge, that individuals are heavily skewed towards seeking (Franke et al. 2013) and offering (Dyer and Nobeoka 2000; Fey and Furu 2008) knowledge within geographical as well as within firm boundaries. Earlier research proposes several mechanisms to alleviate this problem and foster ambidextrous knowledge seeking and offering. Cummings (2004) scrutinized the effects of structural diversity (e.g. organizational affiliations, roles, functions) in work teams. The study concludes that higher degrees of diversity increase the acquisition of knowledge from external sources and thus significantly the acquisition of knowledge for exploration purposes. Still, it should be stressed, that diversity should not extend to the values and norms within organizations. On the contrary, a positive attitude toward knowledge sharing, universal values and consistent norms throughout the company enhance the dissemination of knowledge (Cabrera and Cabrera 2005). To nurture rather exploitative knowledge seeking and offering, the installment of communities of practices at the work place proofed to be successful (Bock et al. 2005). Such communities rely on interpersonal networks, which in turn level the geographical and organizational barriers of knowledge transfer (Singh 2005).

Furthermore, several steps can be taken to bolster ambidextrous knowledge seeking and offering by increasing the willingness of employees to engage in such activities. For one, high levels of self-efficacy increase the likelihood to engage in knowledge sharing (Cabrera and Cabrera 2002). Coaching and feedback can support staff to improve their self-efficacy and knowledge sharing (Cabrera and Cabrera 2002). Secondly, knowledge dissemination is often hampered by the characteristics of knowledge as a public good, that obstruct the ability of knowledge creators to restrict its usage once it is shared with others (Ardichvili et al. 2003). Hence, individuals are not incentivized to offering knowledge or even to seek out knowledge in the first place, if they cannot derive any personal benefits for their efforts. Pay-schemes are able to counter this and encourage knowledge seeking and offering in companies, but these have to be carefully designed (Cabrera and Cabrera 2002). Payments based on individual knowledge contributions or the contributions by specific groups can easily skew any positive effects toward rent-seeking behavior (Bock et al. 2005; Pierce 2012). Successful schemes focus on company-wide knowledge sharing to assess performance (Fey and Furu 2008) to avoid such rent-seeking behavior.

This study confirms the positive association between knowledge accumulation and performance in organizations (Decarolis and Deeds 1999; Melville et al. 2004). This emphasizes further the role of knowledge storage systems to operationalize the memorization in companies (Riege 2005). However, like discussed above, such systems are in need to capture ambidextrous knowledge (flows). Thus, such systems have to possess the capability to save data from very diverse knowledge areas as well as the ability to bridge those diverse areas, so that individuals with little expertise in an area still are able to identify potential opportunities and points of contact. One way to meet this challenge might be to utilize the idea of innovation contests by storing not only the expertise in the storage system, but to describe questions and challenges, which can be answered by experts from other areas (Terwiesch and $\mathrm{Xu}$ 2008). Extending knowledge storage systems from only containing potential solutions towards also including questions, which are asked within the company.

Last but not least, the moderator variable results indicate that managers should consider the innovation focus of the department in question, before determining measures to foster either ambidextrous knowledge seeking or ambidextrous knowledge offering. R\&D management, innovation management or other departments with a higher focus on 
radical innovations benefit especially from structures or processes promoting the offering of knowledge to colleagues. Accordingly, communities of practice should be especially suited in radical-innovation environments. On the other hand, line function departments with a focus on incremental innovations benefit more from structures or processes fostering the seeking of knowledge.

\section{Limitations and further research}

Not unlike other research, this study contains some limitations, which may be promising bridgeheads for further research. First, the analysis utilizes cross-sectional data. However, knowledge flows are dynamic processes, which occur over time. Therefore, an analysis of the process using longitudinal data appears quite promising to gain a deeper understanding of their intricacies.

Second, the data set consist of German respondents. Potential differences of knowledgerelated behavior due to cultural distinctions cannot be measured with such a sample. Culture provides shared norms and values, which serve as basis for generating trust as future behavior is to a greater extend predictable (Doney et al. 1998). This is in particular relevant for knowledge-related behavior due to its characteristics as public good (Szulanski et al. 2004). Namely, once shared the future usage of knowledge cannot be restricted by the original knowledge owner (Cabrera and Cabrera 2002). Stable societies can expect to benefit from a higher predictability by increased knowledge sharing behavior, while in societies in turmoil, the lower predictability leads to an erosion of trust and subsequently knowledge exchange. A vivid empirical example of this mechanism can be found in the transformation occurring through the reunification process in Eastern Germany. In the aftermath of the transformation, which included political uncertainty and increased unemployment, the trust level was significantly lower in Eastern Germany compared to Western Germany (Pollack 1999; Rainer and Siedler 2009). Hence, further research might focus on potential inter-cultural differences and examine how and to which degree knowledge-related behavior, such as ambidextrous knowledge seeking and offerings, depends on cultural norms concerning knowledge-related behavior.

Third, the average age of our sample is rather low. Since we controlled for age in our research model, we believe that the relationships found in our study are rather stable with regard to potential distortion effects by a sample with low average age. Yet, future research might still put age in the center of attention and for instance examine whether age might affect the way knowledge is exchanged in companies.

Fourth, while we found no indication of common method bias within our statistical tests in this regard, we cannot rule out completely that some distortion effects were present due to our single measurement design. Hence, future research might use dyadic data sets of team members and project leaders to have different sources for the independent and dependent variables. Replicating our findings with dyadic data should help in enhancing the external validity of our findings.

Aside from these limitations, the results suggest additional research avenues for further scrutiny. While the importance of initiating individual ambidexterity via ambidextrous knowledge seeking and offering can hardly be overstated, further research into the following (ambidextrous) knowledge development as well as implementation processes are needed to fully comprehend the mechanisms and importance of ambidextrous knowledgerelated behavior. Many factors may impede later staged efforts. The positive results of 
ambidextrous knowledge seeking and offering on performance demonstrate the relevance of this earlier stage, but a full picture may only emerge by also considering the later utilization of knowledge (Szulanski et al. 2016).

Acknowledgements Open Access funding provided by Projekt DEAL.

Open Access This article is licensed under a Creative Commons Attribution 4.0 International License, which permits use, sharing, adaptation, distribution and reproduction in any medium or format, as long as you give appropriate credit to the original author(s) and the source, provide a link to the Creative Commons licence, and indicate if changes were made. The images or other third party material in this article are included in the article's Creative Commons licence, unless indicated otherwise in a credit line to the material. If material is not included in the article's Creative Commons licence and your intended use is not permitted by statutory regulation or exceeds the permitted use, you will need to obtain permission directly from the copyright holder. To view a copy of this licence, visit http://creativecommons.org/licenses/by/4.0/.

\section{References}

Andriopoulos, C., \& Lewis, M. W. (2010). Managing innovation paradoxes: Ambidexterity lessons from leading product design companies. Long Range Planning, 43(1), 104-122.

Ardichvili, A., Page, V., \& Wentling, T. (2003). Motivation and barriers to participation in virtual knowledge-sharing communities of practice. Journal of Knowledge Management, 7(1), 64-77.

Armstrong, J. S., \& Overton, T. S. (1977). Estimating nonresponse bias in mail surveys. Journal of Marketing Research, 14(3), 396-402.

Barney, J. B. (1996). The resource-based theory of the firm. Organization Science, 7(5), 469.

Barrick, J. A., \& Spilker, B. C. (2003). The relations between knowledge, search strategy, and performance in unaided and aided information search. Organizational Behavior and Human Decision Processes, 90(1), 1-18.

Benner, M. J., \& Tushman, M. L. (2003). Exploitation, exploration, and process management: The productivity dilemma revisited. Academy of Management Review, 28(2), 238-256.

Bhaskaran, S. (2006). Incremental innovation and business performance: Small and medium-size food enterprises in a concentrated industry environment. Journal of Small Business Management, 44(1), 64-80.

Bierly, P. E., Damanpour, F., \& Santoro, M. D. (2009). The application of external knowledge: Organizational conditions for exploration and exploitation. Journal of Management Studies, 46(3), 481-509.

Birkinshaw, J., \& Gibson, C. (2004). Building ambidexterity into an organization. MIT Sloan Management Review, 45(4), 47-55.

Birkinshaw, J., \& Gupta, K. (2013). Clarifying the distinctive contribution of ambidexterity to the field of organization studies. The Academy of Management Perspectives, 27(4), 287-298.

Blindenbach-Driessen, F., \& van den Ende, J. (2014). The locus of innovation: The effect of a separate innovation unit on exploration, exploitation, and ambidexterity in manufacturing and service firms. Journal of Product Innovation Management, 31(5), 1089-1105.

Bock, G.-W., Zmud, R. W., Kim, Y.-G., \& Lee, J.-N. (2005). Behavioral intention formation in knowledge sharing: Examining the roles of extrinsic motivators, social-psychological forces, and organizational climate. MIS Quarterly, 29(1), 87-111.

Bodwell, W., \& Chermack, T. J. (2010). Organizational ambidexterity: Integrating deliberate and emergent strategy with scenario planning. Technological Forecasting and Social Change, 77(2), 193-202.

Bresciani, S., Ferraris, A., \& Del Giudice, M. (2018). The management of organizational ambidexterity through alliances in a new context of analysis: Internet of Things (IoT) smart city projects. Technological Forecasting and Social Change, 136, 331-338.

Brettel, M., Mauer, R., Engelen, A., \& Küpper, D. (2012). Corporate effectuation: Entrepreneurial action and its impact on R\&D project performance. Journal of Business Venturing, 27(2), 167-184.

Brucks, M. (1985). The effects of product class knowledge on information search behavior. Journal of Consumer Research, 12(1), 1-16.

Cabrera, A., \& Cabrera, E. F. (2002). Knowledge-sharing dilemmas. Organization Studies, 23(5), 687-710.

Cabrera, E. F., \& Cabrera, A. (2005). Fostering knowledge sharing through people management practices. The International Journal of Human Resource Management, 16(5), 720-735. 
Cash, J. I., Earl, M. J., \& Morison, R. (2008). Teaming up to crack innovation and enterprise integration. Harvard Business Review, 86(11), 90-100.

Chen, C.-J., Lin, B.-W., Lin, J.-Y., \& Hsiao, Y.-C. (2018). Learning-from-parents: exploitative knowledge acquisition and the innovation performance of joint venture. The Journal of Technology Transfer, 45, 1-31.

Chin, W. W. (1998). The partial least squares approach to structural equation modeling. In G. A. Marcoulides (Ed.), Modern methods for business research (pp. 295-336). Mahwah, NJ: Lawrence Erlbaum Associates.

Chin, W. W. (2010). How to write up and report PLS analyses. In V. E. Vinzi, W. W. Chin, J. Henseler, \& H. Wang (Eds.), Handbook of partial least squares (pp. 655-690). Berlin: Springer.

Chin, W. W., \& Newsted, P. R. (1999). Structural equation modeling analysis with small samples using partial least square. Statistical Strategies for Small Sample Research, 1(1), 307-341.

Cohendet, P., \& Laurent, S. (2007). Playing across the playground: Paradoxes of knowledge creation in the videogame firm. Journal of Organizational Behavior, 28(5), 587-605.

Conner, K. R., \& Prahalad, C. K. (1996). A resource-based theory of the firm: Knowledge versus opportunism. Organization Science, 7(5), 477-501.

Cummings, J. N. (2004). Work groups, structural diversity, and knowledge sharing in a global organization. Management Science, 50(3), 352-364.

Davis, F. D. (1989). Perceived usefulness, perceived ease of use, and user acceptance of information technology. MIS Quarterly, 13(3), 319-340.

de Holan, P. M., \& Phillips, N. (2004). Remembrance of things past? The dynamics of organizational forgetting. Management Science, 50(11), 1603-1613.

Decarolis, D. M., \& Deeds, D. L. (1999). The impact of stocks and flows of organizational knowledge on firm performance: An empirical investigation of the biotechnology industry. Strategic Management Journal, 20(10), 953-968.

Dewar, R. D., \& Dutton, J. E. (1986). The adoption of radical and incremental innovations: An empirical analysis. Management Science, 32(11), 1422-1433.

Doney, P. M., Cannon, J. P., \& Mullen, M. R. (1998). Understanding the influence of national culture on the development of trust. Academy of Management Review, 23(3), 601-620.

Dyer, J. H., \& Nobeoka, K. (2000). Creating and managing a high-performance knowledge-sharing network: The toyota case. Strategic Management Journal, 21(3), 345-367.

Fey, C. F., \& Furu, P. (2008). Top management incentive compensation and knowledge sharing in multinational corporations. Strategic Management Journal, 29(12), 1301-1323.

Fornell, C., \& Bookstein, F. L. (1982). Two structural equation models: LISREL and PLS applied to consumer exit-voice theory. Journal of Marketing Research, 19(4), 440-452.

Franke, N., Poetz, M. K., \& Schreier, M. (2013). Integrating problem solvers from analogous markets in new product ideation. Management Science, 60(4), 1063-1081.

Gibson, C. B., \& Birkinshaw, J. (2004). The antecedents, consequences, and mediating role of organizational ambidexterity. Academy of Management Journal, 47(2), 209-226.

Gopalakrishnan, S., \& Bierly, P. (2001). Analyzing innovation adoption using a knowledge-based approach. Journal of Engineering and Technology Management, 18(2), 107-130.

Gopalakrishnan, S., \& Santoro, M. D. (2004). Distinguishing between knowledge transfer and technology transfer activities: The role of key organizational factors. IEEE Transactions on Engineering Management, 51(1), 57-69.

Götz, O., Liehr-Gobbers, K., \& Krafft, M. (2010). Evaluation of structural equation models using the partial least squares (PLS) approach. In V. E. Vinzi, W. W. Chin, J. Henseler, \& H. Wang (Eds.), Handbook of partial least squares (pp. 691-711). Berlin: Springer.

Grant, R. M. (1996). Toward a knowledge-based theory of the firm. Strategic Management Journal, 17(S2), $109-122$.

Gupta, A. K., Smith, K. G., \& Shalley, C. E. (2006). The interplay between exploration and exploitation. Academy of Management Journal, 49(4), 693-706.

Gurtner, S., \& Reinhardt, R. (2016). Ambidextrous idea generation-Antecedents and outcomes. Journal of Product Innovation Management, 33, 34-54.

Hair, J., Sarstedt, M., \& Ringle, C. (2013). Partial least squares structural equation modeling: Rigorous applications, better results and higher acceptance. Long Range Planning, 46, 1-12.

Hansen, M. T. (1999). The search-transfer problem: The role of weak ties in sharing knowledge across organization subunits. Administrative Science Quarterly, 44(1), 82-111.

He, Z.-L., \& Wong, P.-K. (2004). Exploration vs. exploitation: An empirical test of the ambidexterity hypothesis. Organization Science, 15(4), 481-494. 
Helm, S., Eggert, A., \& Garnefeld, I. (2010). Modeling the impact of corporate reputation on customer satisfaction and loyalty using partial least squares. In V. E. Vinzi, W. W. Chin, J. Henseler, \& H. Wang (Eds.), Handbook of partial least squares (pp. 515-534). Berlin: Springer.

Henseler, J., Ringle, C. M., \& Sinkovics, R. R. (2009). The use of partial least squares path modeling in international marketing. In R. Sinkovics \& P. Ghauri (Eds.), New challenges to international marketing. Advances in International Marketing (Vol. 20, pp. 277-319). Bingley: Emerald Group Publishing Limited.

Hill, S. A., \& Birkinshaw, J. (2014). Ambidexterity and survival in corporate venture units. Journal of Management, 40(7), 1899-1931.

Huang, J., \& Kim, H. J. (2013). Conceptualizing structural ambidexterity into the innovation of human resource management architecture: the case of LG Electronics. The International Journal of Human Resource Management, 24(5), 922-943.

Iacobucci, D., \& Duhachek, A. (2004). Roundtable mediation analysis. In B. E. Kahn \& M. F. Luce (Eds.), NA-advances in consumer research (Vol. 31). Valdosta, GA: Association for Consumer Research.

Jansen, J. J. P., Tempelaar, M. P., van den Bosch, F. A. J., \& Volberda, H. W. (2009). Structural differentiation and ambidexterity: The mediating role of integration mechanisms. Organization Science, 20(4), 797-811.

Jasimuddin, S. M., Connell, N., \& Klein, J. H. (2012). Knowledge transfer frameworks: An extension incorporating knowledge repositories and knowledge administration. Information Systems Journal, 22(3), 195-209.

Kammerlander, N., Burger, D., Fust, A., \& Fueglistaller, U. (2015). Exploration and exploitation in established small and medium-sized enterprises: The effect of CEOs' regulatory focus. Journal of Business Venturing, 30(4), 582-602.

Kane, G. C., \& Alavi, M. (2007). Information technology and organizational learning: An investigation of exploration and exploitation processes. Organization Science, 18(5), 796-812.

Kankanhalli, A., Tan, B. C. Y., \& Wei, K.-K. (2005). Contributing knowledge to electronic knowledge repositories: An empirical investigation. MIS Quarterly, 29(1), 113-143.

Kanuk, L., \& Berenson, C. (1975). Mail surveys and response rates: A literature review. Journal of Marketing Research, 12(4), 440.

Kauppila, O.-P. (2018). How does it feel and how does it look? The role of employee motivation in organizational learning type. Journal of Organizational Behavior. https://doi.org/10.1002/job.2270.

Keil, M., Tan, B. C. Y., Wei, K.-K., Saarinen, T., Tuunainen, V., \& Wassenaar, A. (2000). A cross-cultural study on escalation of commitment behavior in software projects. MIS Quarterly, 24(2), 299-325.

Kock, N. (2015). Common method bias in pLS-SEM: A full collinearity assessment approach. International Journal of E-Collaboration (IJeC), 11(4), 1-10.

Kogut, B., \& Zander, U. (1992). Knowledge of the firm, combinative capabilities, and the replication of technology. Organization Science, 3(3), 383-397.

Landry, R., Amara, N., \& Ouimet, M. (2007). Determinants of knowledge transfer: evidence from Canadian university researchers in natural sciences and engineering. The Journal of Technology Transfer, 32(6), 561-592.

Lavie, D., Stettner, U., \& Tushman, M. L. (2010). Exploration and exploitation within and across organizations. Academy of Management Annals, 4(1), 109-155.

Lee, G. K., \& Cole, R. E. (2003). From a firm-based to a community-based model of knowledge creation: The case of the linux kernel development. Organization Science, 14(6), 633-649.

Lee, C.-Y., \& Huang, Y.-C. (2012). Knowledge stock, ambidextrous learning, and firm performance: Evidence from technologically intensive industries. Management Decision, 50(6), 1096-1116.

Leifer, R., O’Connor, G. C., \& Rice, M. (2001). Implementing radical innovation in mature firms: The role of hubs. The Academy of Management Executive, 15(3), 102-113.

Leiponen, A. (2005). Organization of knowledge and innovation: The case of finnish business services. Industry and Innovation, 12(2), 185-203.

March, J. G. (1991). Exploration and exploitation in organizational learning. Organization Science, 2(1), 71-87.

McDermott, C. M., \& O’Connor, G. C. (2002). Managing radical innovation: An overview of emergent strategy issues. Journal of Product Innovation Management, 19(6), 424-438.

McEvily, S. K., \& Chakravarthy, B. (2002). The persistence of knowledge-based advantage: an empirical test for product performance and technological knowledge. Strategic Management Journal, 23(4), 285-305.

Melville, N., Kraemer, K., \& Gurbaxani, V. (2004). Review: Information technology and organizational performance-an integrative model of it business value. MIS Quarterly, 28(2), 283-322. 
Mom, T. J. M., Fourné, S. P. L., \& Jansen, J. J. P. (2015). Managers' work experience, ambidexterity, and performance: The contingency role of the work context. Human Resource Management, 54(S1), s133-s153.

Mom, T. J. M., Van Den Bosch, F. A. J., \& Volberda, H. W. (2007). Investigating managers' exploration and exploitation activities: The influence of top-down, bottom-up, and horizontal knowledge inflows. Journal of Management Studies, 44(6), 910-931.

Mom, T. J. M., van den Bosch, F. A. J., \& Volberda, H. W. (2009). Understanding variation in managers' ambidexterity: Investigating direct and interaction effects of formal structural and personal coordination mechanisms. Organization Science, 20(4), 812-828.

Montazemi, A. R., Pittaway, J. J., Qahri Saremi, H., \& Wei, Y. (2012). Factors of stickiness in transfers of knowhow between MNC units. The Journal of Strategic Information Systems, 21(1), 31-57.

Moorman, C., Diehl, K., Brinberg, D., \& Kidwell, B. (2004). Subjective knowledge, search locations, and consumer choice. Journal of Consumer Research, 31(3), 673-680.

Nunnally, J. C., \& Bernstein, I. H. (1994). Psychometric theory (3rd ed.). New York: McGraw-Hill.

O'Reilly, C. A., \& Tushman, M. L. (2013). Organizational ambidexterity: Past, present, and future. The Academy of Management Perspectives, 27(4), 324-338.

Pérez-Luño, A., Cabello Medina, C., Carmona Lavado, A., \& Cuevas Rodríguez, G. (2011). How social capital and knowledge affect innovation. Journal of Business Research, 64(12), 1369-1376.

Phang, C. W., Kankanhalli, A., \& Sabherwal, R. (2009). Usability and sociability in online communities: A comparative study of knowledge seeking and contribution. The Association of Information Systems, 10, $721-747$.

Pierce, L. (2012). Organizational structure and the limits of knowledge sharing: Incentive conflict and agency in car leasing. Management Science, 58(6), 1106-1121.

Podsakoff, P. M., MacKenzie, S. B., Lee, J.-Y., \& Podsakoff, N. P. (2003). Common method biases in behavioral research: A critical review of the literature and recommended remedies. Journal of Applied Psychology, 88(5), 879-903.

Podsakoff, P. M., \& Organ, D. W. (1986). Self-reports in organizational research: Problems and prospects. Journal of Management, 12(4), 531-544.

Pollack, D. (1999). Trust in institutions and the urge to be different: On attitudinal change in eastern Germany. German Politics, 8(3), 81-102.

Rainer, H., \& Siedler, T. (2009). Does democracy foster trust? Journal of Comparative Economics, 37(2), 251-269.

Raisch, S., \& Birkinshaw, J. (2008). Organizational ambidexterity: Antecedents, outcomes, and moderators. Journal of Management, 34(3), 375-409.

Raisch, S., Birkinshaw, J., Probst, G., \& Tushman, M. L. (2009). Organizational ambidexterity: Balancing exploitation and exploration for sustained performance. Organization Science, 20(4), 685-695.

Riege, A. (2005). Three-dozen knowledge-sharing barriers managers must consider. Journal of Knowledge Management, 9(3), 18-35.

Schenkel, A., \& Teigland, R. (2008). Improved organizational performance through communities of practice. Journal of Knowledge Management, 12(1), 106-118.

Schnellbächer, B., Heidenreich, S., \& Wald, A. (2019). Antecedents and effects of individual ambidexterity-A cross-level investigation of exploration and exploitation activities at the employee level. European Management Journal, 37(4), 442-454.

Schultz, C., Schreyoegg, J., \& von Reitzenstein, C. (2013). The moderating role of internal and external resources on the performance effect of multitasking: Evidence from the R\&D performance of surgeons. Research Policy, 42(8), 1356-1365.

Schulz, M. (2001). The uncertain relevance of newness: organizational learning and knowledge flows. Academy of Management Journal, 44(4), 661-681.

Singh, J. (2005). Collaborative networks as determinants of knowledge diffusion patterns. Management Science, 51(5), 756-770.

Smith, W. K., \& Tushman, M. L. (2005). Managing strategic contradictions: A top management model for managing innovation streams. Organization Science, 16(5), 522-536.

Sobel, M. E. (1982). Asymptotic confidence intervals for indirect effects in structural equation models. Sociological Methodology, 13, 290-312.

SubbaNarasimha, P. N., Ahmad, S., \& Mallya, S. N. (2003). Technological knowledge and firm performance of pharmaceutical firms. Journal of Intellectual Capital, 4(1), 20-33.

Suh, T., Khan, O. J., Schnellbaecher, B., \& Heidenreich, S. (2019). Strategic accord and tension for business model innovation: Examining different tacit knowledge types and open action strategies. International Journal of Innovation Management, 2050039.

Szulanski, G. (2000). The process of knowledge transfer: A diachronic analysis of stickiness. Organizational Behavior and Human Decision Processes, 82(1), 9-27. 
Szulanski, G., Cappetta, R., \& Jensen, R. J. (2004). When and how trustworthiness matters: Knowledge transfer and the moderating effect of causal ambiguity. Organization Science, 15(5), 600-613.

Szulanski, G., \& Jensen, R. J. (2004). Overcoming stickiness: An empirical investigation of the role of the template in the replication of organizational routines. Managerial and Decision Economics, 25(6-7), 347-363.

Szulanski, G., Ringov, D., \& Jensen, R. J. (2016). Overcoming stickiness: How the timing of knowledge transfer methods affects transfer difficulty. Organization Science, 27(2), 304-322.

Tarafdar, M., \& Gordon, S. R. (2007). Understanding the influence of information systems competencies on process innovation: A resource-based view. The Journal of Strategic Information Systems, 16(4), 353-392.

Tenenhaus, M., Vinzi, V. E., Chatelin, Y.-M., \& Lauro, C. (2005). PLS path modeling. Computational Statistics and Data Analysis, 48(1), 159-205.

Terwiesch, C., \& Xu, Y. (2008). Innovation contests, open innovation, and multiagent problem solving. Management Science, 54(9), 1529-1543.

Tiwana, A., \& Keil, M. (2007). Does peripheral knowledge complement control? An empirical test in technology outsourcing alliances. Strategic Management Journal, 28(6), 623-634.

Tödtling, F., Lehner, P., \& Kaufmann, A. (2009). Do different types of innovation rely on specific kinds of knowledge interactions? Technovation, 29(1), 59-71.

Tushman, M. L., \& O'Reilly, C. A. (1996). The ambidextrous organizations: managing evolutionary and revolutionary change. California Management Review, 38(4), 8-30.

Uotila, J. (2018). Punctuated equilibrium or ambidexterity: Dynamics of incremental and radical organizational change over time. Industrial and Corporate Change, 27(1), 131-148.

Vinzi, V. E., \& Russolillo, G. (2013). Partial least squares algorithms and methods. Wiley Interdisciplinary Reviews: Computational Statistics, 5(1), 1-19.

von Krogh, G., Nonaka, I., \& Aben, M. (2001). Making the most of your company's knowledge: A strategic framework. Long Range Planning, 34(4), 421-439.

Vrontis, D., Thrassou, A., Santoro, G., \& Papa, A. (2017). Ambidexterity, external knowledge and performance in knowledge-intensive firms. The Journal of Technology Transfer, 42(2), 374-388.

Walrave, B., Romme, A. G. L., van Oorschot, K. E., \& Langerak, F. (2017). Managerial attention to exploitation versus exploration: Toward a dynamic perspective on ambidexterity. Industrial and Corporate Change, 26(6), 1145-1160.

Ward, T. B. (2004). Cognition, creativity, and entrepreneurship. Journal of Business Venturing, 19(2), $173-188$.

Wei, Z., Yi, Y., \& Guo, H. (2014). Organizational learning ambidexterity, strategic flexibility, and new product development. Journal of Product Innovation Management, 31(4), 832-847.

Wetzels, M., Odekerken-Schröder, G., \& van Oppen, C. (2009). Using PLS path modeling for assessing hierarchical construct models: Guidelines and empirical illustration. MIS Quarterly, 33(1), 177-195.

Yli-Renko, H., Autio, E., \& Sapienza, H. J. (2001). Social capital, knowledge acquisition, and knowledge exploitation in young technology-based firms. Strategic Management Journal, 22(6-7), 587-613.

Zhang, W., Zhao, Y., Wang, D., Wang, H., \& Li, J. (2017). Ambidextrous search and product innovation: Moderating effects of resource and structural attributes. The Journal of Technology Transfer, 2017, 1-12.

Zhou, K. Z., \& Li, C. B. (2012). How knowledge affects radical innovation: Knowledge base, market knowledge acquisition, and internal knowledge sharing. Strategic Management Journal, 33(9), 1090-1102.

Zhou, K. Z., \& Wu, F. (2010). Technological capability, strategic flexibility, and product innovation. Strategic Management Journal, 31(5), 547-561.

Publisher's Note Springer Nature remains neutral with regard to jurisdictional claims in published maps and institutional affiliations. 